REVIEW ARTICLE

J. Food Sci. Technol. Nepal, Vol. 10 (48-54), 2018

ISSN: 1816-0727

\title{
Brown Rice: Nutritional Composition and Health Benefits
}

\author{
ATUL UPADHYAY ${ }^{1 *}$ AND SANJEEV KUMAR KARN ${ }^{2}$
}

\author{
${ }^{1}$ Nepal Food Scientists and Technologists Association, Babarmahal, Kathmandu, Nepal \\ ${ }^{2}$ Department of Food Technology and Quality Control, Babarmahal, Kathmandu, Nepal
}

\begin{abstract}
Brown rice is the unmilled rice with pericarp, the seed coat and nucellus, the germ or the embryo, and the endosperm. It is whole grain rice with intact bran layer and the inedible outer hull removed. Although it has several health claims, it is mostly consumed by a limited number of health conscious and nutritionally aware people. In this paper, we discuss the physiochemical properties of brown rice along with its health benefits, including certain cancers.
\end{abstract}

Keywords: Brown Rice, Nutritional Composition

\section{Introduction}

Rice is the staple food of about half of the world population supplying more than $21 \%$ of total calorie requirement for those people and about $76 \%$ of South East Asians (Fitzgerald et al., 2009; Shinde et al., 2014) . In Thailand, rice provides about $41 \%$ of total daily energy intake (FAOSTAT, 2015). Food consumption patterns from the Malaysian adult nutrition survey revealed that cooked rice was consumed by $97 \%$ of the population twice daily (Norimah et al., 2008).

Malnutrition and chronic diseases are widespread in most of the developing countries where white rice is the main staple food (Dipti et al., 2012) while many researchers have reported that brown rice contained the essential nutrients like iron, zinc, thiamine, niacin, vitamin E, dietary fiber, protein and carbohydrate (Pascual et al., 2013; Sabularse et al., 1991). Furthermore, bioactive constituents such as $\gamma$ oryzanols, tocotrienols, polyphenols have also been identified from brown rice (Leardkamolkarn et al., 2011). In addition, some varieties of brown rice were found to be low in glycemic index (GI) (Brand-Miller et al., 1992; Jenkins et al., 1981) and evidences have shown that low glycemic index (GI) food has many health benefits such as control type II diabetes (Greenwood et al., 2013), prevent coronary heart diseases (Hallfrisch et al., 2003; Mirrahimi et al., 2014), obesity and cancers (Nagle et al., 2013; Romieu et al., 2012). However, GI of rice were reported to be affected by various factors like variety, geography, method of processing conditions (Brand-Miller et al., 1992), nature of the starch, cooking method, presence of fiber, and other nutrients content such as fat and protein (Wolever and Mehling, 2002). Hence, brown rice has potential to reduce the prevalence of malnutrition and chronic disease (Anderson et al., 2009; Dipti et al., 2012).

In Nepal, rice is the most important and prestigious food crop and is grown as high as $3,050 \mathrm{~m}$ above the sea level (NARC, 2016). It is grown over 1.4 million ha, with the productivity of $2.56 \mathrm{t} / \mathrm{ha}$. It contributes nearly $20 \%$ to the agricultural GDP and provides more than 50\% of the total calorie requirement of the Nepalese people (NARC, 2016). Several varieties of white rice have been developed in the country, however, only a very few are available as commercial brown rice in the stores. In this article, we discuss the nutritional composition of brown rice and losses during milling and the health benefits of brown rice over milled rice.

\section{Brown Rice}

Brown rice is whole grain rice with intact bran layer and the inedible outer hull removed. It is the unmilled rice containing the pericarp, the seed coat and nucellus, the germ or embryo, and the endosperm (Ajimilah \& Rosniyana, 1995). The dark color of brown rice is due to the bran layer and is rich in vitamins like thiamine, niacin, pyridoxine, and minerals like manganese, phosphorus, and iron (Babu et al., 2009). Although brown rice contains several vitamins and minerals, it is only consumed by a limited number of health conscious and nutritionally aware people (Roy et al., 2008), probably due to its longer cooking time, instability during storage, strong bran flavor, and undesirable texture.

Mostly, the brown rice production in Nepal is done locally in the villages using traditional equipment called dhiki, a special de-husking instrument made generally of wood. After threshing, paddy is dehulled using dhiki, generally operated by one or two persons using foot (Figure 2). In Nepal, the commercial brown rice production has started in one industry with a total production of less than $50 \mathrm{M}$ ton (Personal Communication, September 11, 2016), compared to a total import of more than $3000 \mathrm{M}$ ton from India in 2015 (UNSD, 2016). Commercially, brown rice is obtained after the de-husked grains are graded, color-sorted, and damaged or broken grains removed from the mixture. This results in considerable loss resulting in only around $65-70 \%$ recovery of the total paddy (Personal Communication, September 11, 2016). However, the recovery of brown rice depends on the quality and variety of paddy used. The brown rice recovery ranged from $78.6 \%$ in Mithila variety compared to $82.6 \%$ in Radha 4 variety (NARC, 2015). Further detailed investigations are required to obtain the production and consumption data of brown rice in Nepal.

\section{Nutritional composition of Brown rice}

The dehulling of paddy results in brown rice with least damage to its nutritional quality; but further milling and polishing to obtain white rice results in significant losses of vital nutrients (Table 1). The major key nutrient of brown rice such as fiber, antioxidants, phytoestrogens, minerals and vitamins are concentrated in bran layer which is removed during the milling process to improve the hardness and 
chewiness (Das et al. 2008; Wang et al., 2013) (Fig. 1). Rice bran constitutes $10 \%$ of total rice grain and contains the major part of nutrients and antioxidative components such as vitamin E (tocopherols and tocotrienols), phytosterols, phytic acid, phenols, $\gamma$-oryzanols and tricin (Leardkamolkarn et al., 2011).

Nutritional studies have identified dietary fiber, bran oil, unsaponifiable matter, sterols and protein as rice bran's healthful components (Slavin, 2004). Composition of the whole grain rice is almost similar to the whole cereal grains though it contains some unique components in unique amount (Dipti et al., 2012). Milling of brown rice causes minimum loss of protein and carbohydrate, but significant losses (in the range of $60-90 \%$ ) of other components like fiber, lipids, minerals, B-vitamins (USDA, 2014).

Brown rice, generally, contains fiber three times more than white rice (Parengam et al., 2012). The insoluble dietary fiber enhances the weight of stool, prevents carcinogens actions in intestinal mucosa, easy emptying of faeces and supports normal colonic microfloral growth to produce beneficial components such as short chain fatty acids (Willet et al., 1992; Daou and Zhang, 2014). The dietary fibers also have potentials to reduce serum cholesterol, low density lipoprotein and blood pressure, and to improve glycaemia and insulin sensitivity (Glore et al., 1994; Thebaudin et al., 1997; Anderson et al., 2009; Yanai et al; 2014).

The B-vitamins present in the brown rice may play a significant role in preventing diseases associated with vitamin deficiencies. The deficiency of thiamine causes beriberi, with symptoms of weakness, loss of sensation in the legs and cardiac failures (Adamolekun, 2010). Several consequences of thiamine deficiencies have been seen in different countries, including Nepal (WHO, 2007). Certain varieties of brown rice has been reported to contain more than $0.5 \mathrm{mg} / 100 \mathrm{~g}$ thiamine (McKevith, 2004; Deepa et al., 2008). Similarly, niacin is considered important for its role as nicotinamide adenine phosphate (NAD), and important prosthetic group of several types of enzymes (Batifoulier et al., 2006). Among grains and legumes, brown rice is considered good source of niacin which contains up to 5.54 $\mathrm{mg} / 100 \mathrm{~g}$ (Lebiedzinska and Szefer, 2006) (Table 2).

The mineral content of brown rice have varying amount of iron $(\mathrm{Fe})$, phosphorus $(\mathrm{P})$, magnesium $(\mathrm{Mg})$, Potassium $(\mathrm{K})$, zinc $(\mathrm{Zn})$, and copper $(\mathrm{Cu})$ (Table 2$)$. Polished rice diets with low amount of trace minerals are thought to be reasons for anemia and $\mathrm{Zn}$ deficiencies disorders in certain population (Dipti et al., 2012). WHO estimates that more than $30 \%$ of the world population are anemic, mainly due to Fe deficiency (WHO, 2015). Brown rice contains the highest amount of Fe compared to husk, chaff and raw polished rice (Meng et al., 2005). However, it should be noted that certain anti-nutritional factors like phytate present in the brown rice may reduce the bioavailability of bivalent minerals. Certain processing like soaking, germination and fermentation may reduce the phytic acid and increase the bioavailability of metals (Liang et al., 2008).

The rice protein is mainly found in protein bodies between starch granules, however, bran also contains considerable amount of protein (Juliano and Bechtel, 1985). Furthermore, the rice protein quality has been better in comparison to wheat and corn protein quality (Cao et al., 2009). The protein content of brown rice varies in the range of $4.3-$ $18.2 \%$, and has higher amounts of lysine, and essential amino acid, in comparison to other cereals and milled rice (Deepa et al., 2008). The major carbohydrate present in the brown rice is starch, which is a homopolymer of glucose forming an alpha-glucosidic chain, called glucosan or glucan. The two main constituents of starch are amylose and amylopectin. However, rice contains lower proportion of lipid than starch and protein. The lipid is concentrated in embryo or germ of the kernel and also in aleurone layer (Juliano, 1985). The rice lipid is unique source of bioactive compounds like vitamin E, y-oryzanol (Lerma-Garcia et al., 2009; Yoshida et al., 2011).

Table 1. Nutrient compositions of brown and white rice (per $100 \mathrm{~g}$ Long grain, raw)

\begin{tabular}{|c|c|c|c|c|}
\hline Nutrient & Unit & $\begin{array}{l}\text { Brown } \\
\text { rice }\end{array}$ & $\begin{array}{l}\text { White } \\
\text { rice }\end{array}$ & $\begin{array}{l}\% \\
\text { milling } \\
\text { loss * }\end{array}$ \\
\hline Moisture & g & 10.37 & 11.62 & - \\
\hline Protein & $\mathrm{g}$ & 7.94 & 7.13 & 10 \\
\hline Total lipid (fat) & g & 2.92 & 0.66 & 77 \\
\hline $\begin{array}{l}\text { Carbohydrate, by } \\
\text { difference }\end{array}$ & $\mathrm{g}$ & 77.24 & 79.95 & - \\
\hline Fiber (total dietary) & g & 3.5 & 1.3 & 63 \\
\hline Total sugars & g & 0.85 & 0.12 & 86 \\
\hline Calcium, $\mathrm{Ca}$ & $\mathrm{mg}$ & 23 & 28 & - \\
\hline Iron, $\mathrm{Fe}$ & $\mathrm{mg}$ & 1.47 & 0.8 & 46 \\
\hline Magnesium, Mg & $\mathrm{mg}$ & 143 & 25 & 83 \\
\hline Phosphorus, $\mathrm{P}$ & $\mathrm{mg}$ & 333 & 115 & 66 \\
\hline Potassium, Ka & $\mathrm{mg}$ & 223 & 115 & 49 \\
\hline Sodium, $\mathrm{Na}$ & $\mathrm{mg}$ & 7 & 5 & 29 \\
\hline Zinc, Zn & $\mathrm{mg}$ & 2.02 & 1.09 & 46 \\
\hline Thiamine & $\mathrm{mg}$ & 0.401 & 0.07 & 83 \\
\hline Riboflavin & $\mathrm{mg}$ & 0.093 & 0.049 & 47 \\
\hline Niacin & $\mathrm{mg}$ & 5.091 & 1.6 & 69 \\
\hline Vitamin B6 & $\mathrm{mg}$ & 0.509 & 0.164 & 68 \\
\hline Folate & $\mu \mathrm{g}$ & 20 & 8 & 60 \\
\hline $\begin{array}{l}\text { Vitamin } \\
\text { tocopherol })\end{array} \quad \mathrm{E} \quad(\alpha-$ & $\mathrm{mg}$ & 1.2 & 0.11 & 91 \\
\hline FA (total saturated) & g & 0.584 & 0.18 & 69 \\
\hline $\begin{array}{l}\text { FA (total } \\
\text { monounsaturated) }\end{array}$ & $\mathrm{g}$ & 1.056 & 0.206 & 80 \\
\hline $\begin{array}{l}\text { FA (total } \\
\text { polyunsaturated) }\end{array}$ & $\mathrm{g}$ & 1.044 & 0.177 & 83 \\
\hline
\end{tabular}

*Calculated on the basis of difference in brown and white rice; FA, Fatty acids

Source: USDA National Nutrient Database for Standard Reference (2014) (Adapted)

\section{Physico-chemical properties of brown rice}

The physicochemical properties such as dimension and appearance are regarded as the important indicators of rice properties (Deepa et al., 2008; Shinde et al., 2014). These indicators include kernel dimensions, and chemical properties like amylose content, gelatinization temperature, gel consistency, water uptake, solid loss of rice during hydration and sensory characteristics. All these indicators are considered while evaluating cooking quality of rice (Shinde et al., 2014). Brown rice can be classified as long ( $>3.1 \mathrm{~mm})$, medium $(2.1-3 \mathrm{~mm})$ and short $(<2 \mathrm{~mm})$ (Aluko et al., 2004). Similarly, brown rice with high 
amylose $(25-30 \%)$, intermediate $(20-25 \%)$, and low (10$20 \%)$ are also found. Generally, long grains with high amylose content becomes dry, flaky and separate after cooking; the shorter and medium grains with low amylose impart moist and firm after cooking (Deepa et al., 2010). More is the gelatinization temperature $\left(>80{ }^{\circ} \mathrm{C}\right.$ ), higher is the resistance to water uptake and starch gelatinization (Sabularse et al., 1991). Rice with higher gelatinization temperature has longer cooking time than milled rice, however, higher cooking time of brown rice is considered due to slow water absorption because of the presence of thick and intact aleurone and pericarp (Rosniyana et al., 2006; Deepa et al., 2008). The cooking time of brown rice can be reduced through ultrasonic treatment, albeit, there is a loss in natural morphology of the rice bran (Cui et al., 2010).

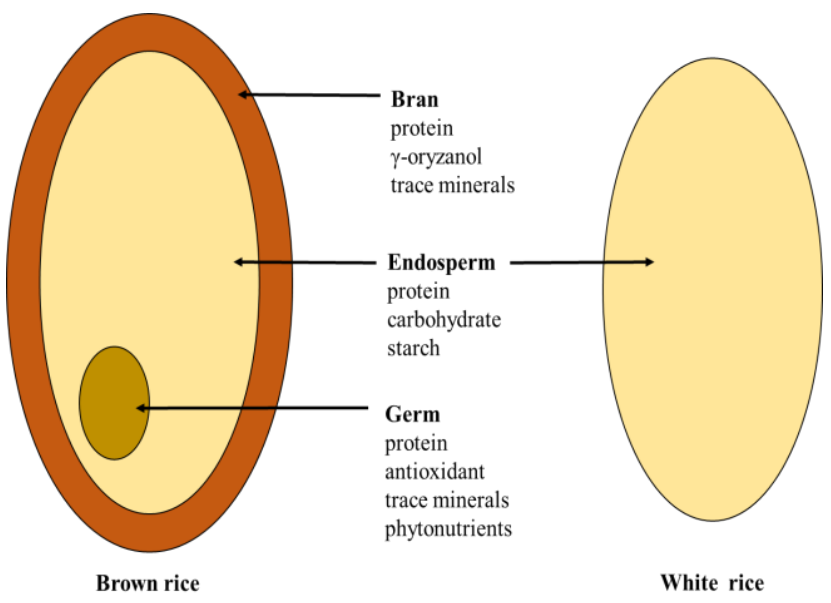

Figure 1. Hypothetical diagram of brown and white rice

\section{Health benefits of brown rice}

In some parts of the world, "to eat" literally means "to eat rice" (Babu et al., 2009). This is probably due to accessibility of some variety of rice throughout the year, and the cultural practices of eating rice three times a day. Therefore, rice consumption has resulted in providing at least $50 \%$ of total calorie intake in these regions.

The milling and polishing of brown rice to white rice results in significant losses of micro nutrients (Table 1). The chemical composition of brown rice was significantly affected by the milling process (Rosniyana et al., 2006). Therefore, brown rice and partially milled rice offer healthier benefits than milled rice. With high fiber content, brown rice can protect against several colonic disorders. High rice fiber intake causes changes in the microbial populations, in particular, significantly higher numbers of Bifidobacterium adolescentis and Enterococcus faecalis and significantly lower number so baceteroides, eubacteria, and clostridia (Benno et al., 1989).

Several types of antioxidant phenolic compounds have been isolated from brown rice and it has been reported that these compounds more abundant in brown than white rice (Tian et al., 2004). Furthermore, it has been suggested that brown rice and bran contain compound such as tricin which could be associated with the putative cancer chemopreventive properties, and that these compounds are found in higher amounts in brown rice than white rice (Hudson et al., 2000). Furthermore, a clear inverse association between whole- grain, like brown rice, intake and risk of ischemic heart disease death exists, which may be due to the presence of phytochemicals, including fiber and antioxidants (Jacobs Jr et al., 1998). Moreover, epidemiological studies have indicated that individuals with higher levels of whole grain intake have a 29\% lower risk for atherosclerotic cardiovascular disease (Anderson, 2003). These diets tend to decrease serum LDL-cholesterol and triacylglycerol levels as well as blood pressure while increasing HDL-cholesterol levels (Anderson, 2003).

Substitution of whole grains, including brown rice, for white rice may lower risk of type 2 diabetes (Sun et al., 2010). This could be attributed to the lower glycemic index (GI) of brown rice (66) than white rice (72) (Jenkins et al., 1981). Low GI foods have been extensively studied and association for the reduction of urinary C-peptide excretion, improvement on glycemic control of diabetic, reduction of serum lipids, enhancement of HDL-cholesterol, reduction of risk of cardiovascular diseases as well as cancers have been found (Jenkins et al., 1981; Wolever \& Mehling, 2002; Romieu et al., 2012; Greenwood et al., 2013). Brown rice is a more health beneficial food for diabetics and hypoglycemic individuals since it releases less amount of glucose to the blood than compared to white rice (Panlasigui, et al., 2006). Studies have suggested that modifying the type or rice consumed and choosing low GI snacks could have a major influence on the total meal glycaemic load of young children (Hui \& Nelson, 2006).

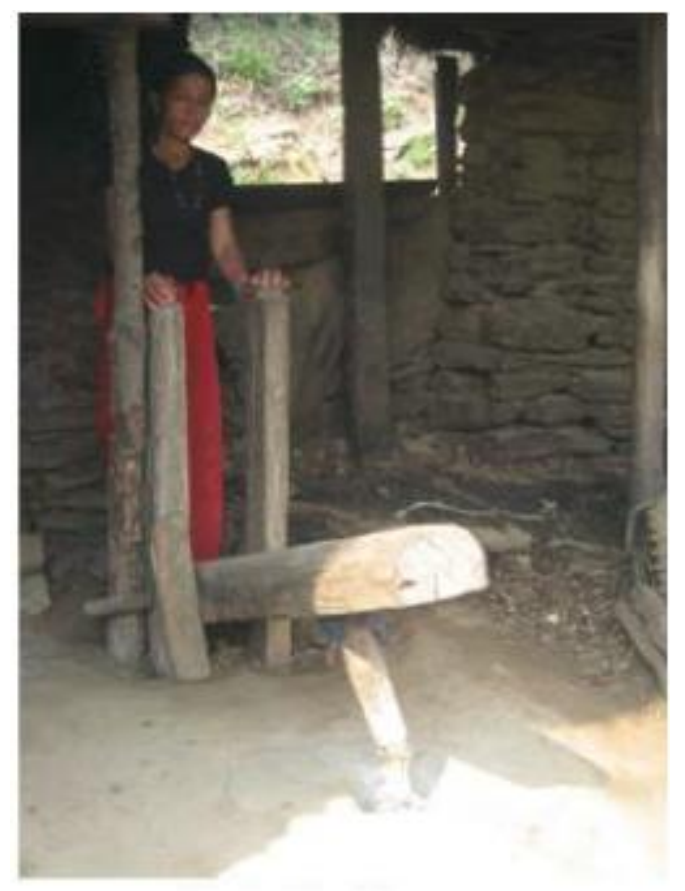

Figure 2. Traditional dehulling equipment, dhiki, being operated by Nepalese woman. (Adapted from Joshi, 2014).

\section{Concluding Remarks}

The nutritional composition of brown rice has several advantages of milled rice, primarily due to the presence of several phytochemicals like fiber, vitamins, minerals, monoand poly-unsaturated fatty acids, and antioxidant 
phytochemicals. However, significant amount of these constituents are lost during the milling or polishing process. The evidences suggest that brown rice has life style disease preventing potentialities, and therefore, it is highly recommended to substitute brown rice with milled rice in diets.

\section{References}

Adamolekun, B. (2010). Thiamine deficiency and the etiology of tropical ataxic neuropathy. International Health, 2(1), 17-21.

Ajimilah, N.H. and Rosniyana, A. (1994). Brown rice consumption in Malaysia: A new trend? Proceeding of 5th ASEAN FOOD Conference. Kuala Lumpur: MARDI

Aluko, G., Martinez, C., Tohme, J., Castano, C., Bergman, C., \& Oard, J. H. (2004). QTL mapping of grain quality traits from the interspecific cross Oryza sativa x $O$. glaberrima. TAG. Theoretical and Applied Genetics, 109(3), 630-9.

Anderson, J.W. (2003). Whole grains protect against atherosclerotic cardiovascular disease. Proceedings of the Nutrition Society, 62, 135-142.

Anderson, J. W., Baird, P., Davis, R. H., Ferreri, S., Knudtson, M., Koraym, A., Williams, C. L. et al. (2009). Health benefits of dietary fiber. Nutrition Reviews, 67, 188205.

Babu, D.P., Subhasree, R.S., Bhakyaraj, R., \& Vidhyalakshmi, R. (2009). Brown rice-beyond the color reviving a lost health food - a review. American-Eurasian Journal of Agronomy, 2 (2): 67-72.

Batifoulier, F., Verny, M.-A., Chanliaud, E., Rémésy, C., \& Demigne, C. (2006). Variability of B vitamin concentrations in wheat grain, milling fractions and bread products. European Journal of Agronomy, 25, 163-169.

Benno, Y., Endo, K., Miyoshi, H., Okuda, T. (1989). Effect of rice fiber on human fecal microflora. Microbialogy Immunoloyg, 33, 435-440.

Brand Miller, J., Pang, E., \& Bramall, L. (1992). Rice : a high or low glycemic food ? American Journal of Clinical Nutrition, 56, 1035-6.

Cao, X., Wen, H., Li, C., \& Gu, Z. (2009). Differences in functional properties and biochemical characteristics of congenetic rice proteins. Journal of Cereal Science, 50, 184189.

Cui, L., Pan, Z., Yue, T., Atungulu, G. G., \& Berrios, J. (2010). Effect of Ultrasonic Treatment of Brown Rice at Different Temperatures on Cooking Properties and Quality. Cereal Chemistry, 87, 403-408.

Daou, C., \& Zhang, H. (2014). Functional and physiological properties of total, soluble, and insoluble dietary fibres derived from defatted rice bran. Journal of Food Science and Technology, 51, 3878-3885.

Das, M., Banerjee, R., \& Bal, S. (2008). Evaluation of physicochemical properties of enzyme treated brown rice (Part B). LWT - Food Science and Technology, 41, 20922096.

Deepa, G., Singh, V., \& Naidu, K. A. (2008). Nutrient composition and physicochemical properties of Indian medicinal rice - Njavara. Food Chemistry, 106, 165-171.

Deepa, G., Singh, V., \& Naidu, K. A. (2008). Nutrient composition and physicochemical properties of Indian medicinal rice - Njavara. Food Chemistry, 106, 165-171.

Dipti, S. S., Bergman, C., Indrasari, S. D., Herath, T., Hall, R., Lee, H., et al. (2012). The potential of rice to offer solutions for malnutrition and chronic diseases. Rice (New York, N.Y.), 5, 16.

FAOSTAT. (2015). Food Balance Sheet. Retrieved August 28, 2016, from http://faostat3.fao.org/download/FB/FBS/E.

Fitzgerald, M. A., McCouch, S. R., \& Hall, R. D. (2009). Not just a grain of rice: the quest for quality. Trends in Plant Science, 14(3), 133-139.

Glore, S. R., Van Treeck, D., Knehans, A. W., \& Guild, M. (1994). Soluble fiber and serum lipids: a literature review. Journal of the American Dietetic Association, 94(4), 425436.

Greenwood, D. C., Threapleton, D. E., Evans, C. E. L., Cleghorn, C. L., Nykjaer, C., Woodhead, C., \& Burley, V. J. (2013). Glycemic index, glycemic load, carbohydrates, and type 2 diabetes: systematic review and dose-response metaanalysis of prospective studies. Diabetes Care, 36, 41664171 .

Hallfrisch, J., Scholfield, D. J., \& Behall, K. M. (2003). Blood pressure reduced by whole grain diet containing barley or whole wheat and brown rice in moderately hypercholesterolemic men. Nutrition Research, 23, 16311642.

Hudson, E.A., Dinh, P.A., Kokubun, T., Simmonds, M.S.J., \& Gescher, A. (2000). Characterization of potentially chemopreventive phenols in extracts of brown rice that inhibit the growth of human breast and colon cancer cells. Cancer Epidemiology Biomarkers Preview, 9, 1163-1170.

Hui, L.L., \& Nelson, E.A.S. (2006). Meal glycaeming load of normal-weight and overweight Hong Kong children. European Journal of Clinical Nutrition, 60, 220-227.

Jacobs Jr, D.R., Meyer, K.A., Kushi, L.H., \& Folsorn, A.R. (1998). Whole-grain intake may reduce the risk of ischemic heart disease death in postmenopausal women: the Iowa Women's Health Study. American Journal of Clinical Nutrition. 68, 248-257. 
Jenkins, D. J., Wolever, T. M., Taylor, R. H., Barker, H., Fielden, H., Baldwin, J. M., et al. (1981). Glycemic index of foods: a physiological basis for carbohydrate exchange. American Journal of Clinical Nutrition, 34, 362-366.

Juliano, B. O. (1985). Polysaccharides, proteins and lipids. In B. O. Juliano (Ed.), Rice : Chemistry and Technology (pp. 59-142). Minnesota, USA: American Association of Cereal Chemists.

Juliano, B. O., \& Bechtel, D. B. (1985). The rice grain and its gross composition. In B. O. Juliano (Ed.), Rice: Chemistry and Technology (pp. 17-50). Minnesota: American Association of Cereal Chemists.

Joshi, B.K. (2014). Farmers' knowledge on and on-station characterization of bhate phaper (rice tartary buckwheat). Nepal Agriculture Research Journal, 14, 44-52)

Leardkamolkarn, V., Thongthep, W., Suttiarporn, P., Kongkachuichai, R., Wongpornchai, S., \& Wanavijitr, A. (2011). Chemopreventive properties of the bran extracted from a newly-developed Thai rice: The Riceberry. Food Chemistry, 125(3), 978-985.

Lebiedzińska, A., \& Szefer, P. (2006). Vitamins B in grain and cereal-grain food, soy-products and seeds. Food Chemistry, 95(1), 116-122.

Lerma-García, M. J., Herrero-Martínez, J. M., SimóAlfonso, E. F., Mendonça, C. R. B., \& Ramis-Ramos, G. (2009). Composition, industrial processing and applications of rice bran $\gamma$-oryzanol. Food Chemistry, 115(2), 389-404.

Liang, J., Han, B.Z., Mout, M.J.R., \& Hamer, R.J. (2008). Effects of soaking, germination and fermentation on phytic acid, total and in vitro zinc in brown rice. Food Chemistry, $110,821-828$.

Mckevith, B. (2004). Nutritional aspects of cereals, 111142.

Meng, F., Wei, Y., \& Yang, X. (2005). Iron content and bioavailability in rice. Journal of Trace Elements in Medicine and Biology, 18(4), 333-338.

Mirrahimi, A., Chiavaroli, L., Srichaikul, K., Augustin, L. S. A., Sievenpiper, J. L., Kendall, C. W., \& Jenkins, D. J. (2014). The role of glycemic Index and glycemic load in cardiovascular disease and its risk factors: a review of the recent literature. Current Atherosclerosis Reports, 16, 1-10.

Moongngarm, A., \& Saetung, N. (2010). Comparison of chemical compositions and bioactive compounds of germinated rough rice and brown rice. Food Chemistry, 122(3), 782-788.

Nagle, C. M., Olsen, C. M., Ibiebele, T. I., Spurdle, A. B., \& Webb, P. M. (2013). Glycemic index, glycemic load and endometrial cancer risk: results from the Australian National Endometrial Cancer study and an updated systematic review and meta-analysis. European Journal of Nutrition, 52, 705715 .

NARC (2015). Nepal Agricultural Research Council. Annual report of Food Research Division for FY 2069/70 and FY 2070/71.

NARC (2016). Nepal Agricultural Research Council. Nepal Rice Knowledge Bank. Retrieved on 28 August 2016 from http://www.narc.org.np/rice_knowledge_bank/.

Norimah, a. K., Safiah, M., Jamal, K., Siti, H., Zuhaida, H., Rohida, S., et al. (2008). Food consumption patterns: Findings from the Malaysian Adult Nutrition Survey (MANS). Malaysian Journal of Nutrition, 14(1), 25-39.

Panlasigui, L.N. \& Thompson, L.U. (2006). Blood glucose lowering effects of brown rice in normal and diabetic subjects. International Journal of Food Sciences and Nutrition, 57, $151-158$.

Parengam, M., Judprasong, K., Srianujata, S., Jittinandana, S., Laoharojanaphand, S., \& Busamongko, A. (2010). Study of nutrients and toxic minerals in rice and legumes by instrumental neutron activation analysis and graphite furnace atomic absorption spectrophotometry. Journal of Food Composition and Analysis, 23(4), 340-345.

Pascual, C. D. S. C. I., Massaretto, I. L., Kawassaki, F., Barros, R. M. C., Noldin, J. A., \& Marquez, U. M. L. (2013). Effects of parboiling, storage and cooking on the levels of tocopherols, tocotrienols and $\gamma$-oryzanol in brown rice (Oryza sativa L.). Food Research International, 50(2), 676-681.

Romieu, I., Ferrari, P., Rinaldi, S., Slimani, N., Jenab, M., Olsen, A., et al. (2012). Dietary glycemic index and glycemic load and breast cancer risk in the European Prospective Investigation into Cancer and Nutrition (EPIC). The American Journal of Clinical Nutrition, 96, 345-355.

Rosinarse, V. C., Liuzzo, J. a., Rao, R. M., \& Grodner, R. M. (1991). Cooking Quality of Brown Rice as influenced by gamma irradiation, variety and storage. Journal of Food Science, 56, 96-98.

Rosniyana, A., Rukunudin, I. H., \& Norin, S.A.S. (2006). Effects of milling degree on the chemical composition, physico- chemical properties and cooking characteristics of brown rice. Journal of Tropical Agriculture and Food Science, 34(1), 37-44.

Roy, P., Ijiri, T., Okadome, H., Nei, D., Orikasa, T., Nakamura, N., \& Shiina, T. (2008). Effect of processing conditions on overall energy consumption and quality of rice (Oryza sativa L.). Journal of Food Engineering, 89(3), 343348.

Shinde, Y. H., Vijayadwhaja, A., Pandit, A. B., \& Joshi, J. B. (2014). Kinetics of cooking of rice: A review. Journal of Food Engineering, 123, 113-129. 
Slavin, J. (2004). Whole grains and human health. Nutrition Research Reviews, 17, 99-110.

Sun, Q., Spiegelman, D., van Dam, R.M., Holmes, M.D., Malik, V.S., Willet, W.C., \& Hu, F.B. (2010). White rice, brown rice, and risk of type 2 diabetes in US men and women. Archives of Internal Medicine, 170, 961-969.

Tian, S., Nakamura, K., \& Kayahara, H. (2004). Analysis of phenolic compounds in white rice, brown rice, and germinated brown rice. Journal of Agricultural and Food Chemistry, 52, 4808-4813.

Thebaudin, J. Y., Lefebvre, A. C., Harrington, M., \& Bourgeois, C. M. (1997). Dietary fibres: nutritional and technological interest. Trends in Food Science \& Technology, 8(2), 41-48.

USDA National Nutrient Database for Standard Reference. (2014). Food Group: 20 Cereal Grains and Pasta. Retrieved January 1, 2015, from https://www.ars.usda.gov/SP2UserFiles/Place/80400525/Dat a/SR27/reports/sr27fg20.pdf

UNSD (2016). United Nations Statistics Division. United Nations Commodity Trade Statistics Database. Retrieved on $1 \quad$ September, $2016 \quad$ from http://comtrade.un.org/db/dqBasicQueryResults.aspx?cc=10 0620\&px $=\mathrm{H} 1 \& \mathrm{r}=524 \& \mathrm{y}=2015$

Wang, B., Medapalli, R., Xu, J., Cai, W., Chen, X., He, J. C., \& Uribarri, J. (2013). Effects of a whole rice diet on metabolic parameters and inflammatory markers in prediabetes. E-SPEN Journal, 8(1), e15-e20.

WHO (2015). World Health Organization. Micronutrient deficiencies. Global Targets 2025. WHO Global Database on Anaemia. http:// http://www.who.int/nutrition/topics/ida/en/. Retreived on 30 August, 2016.

Willet, W. C., Hunter, D. J., Stampfer, M. J., Colditz, G., Manson, J. E., Spiegelman, D., et al. (1992). Dietary fat and fiber in relation to risk of breast cancer. Journal of American Medical Association, 268, 2037-2041.

Wolever, T. M. S., \& Mehling, C. (2002). Highcarbohydrate - low-glycaemic index dietary advice improves glucose disposition index in subjects with impaired glucose tolerance. British Journal of Nutrition, 87, $477-487$.

WHO (2007). World Health Organization. Thiamine deficiency and its prevention and control in major emergencies. Geneva; 1999. WHO/NHD/99.13.

Yanai, H., Katsuyama, H., Hamasaki, H., Abe, S., Tada, N., \& Sako, A. (2014). Effects of carbohydrate and dietary fiber intake, glycemic index and glycemic load on HDL metabolism in Asian populations. Journal of Clinical Medical Research, 6(5), 321-326.
Yoshida, H., Tanigawa, T., Yoshida, N., Kuriyama, I., Tomiyama, Y., \& Mizushina, Y. (2011). Lipid components, fatty acid distributions of triacylglycerols and phospholipids in rice brans. Food Chemistry, 129(2), 479-484.

Source: USDA National Nutrient Database for Standard Reference (2014) (Adapted)

Table 2. B-vitamins and minerals composition of different brown rice

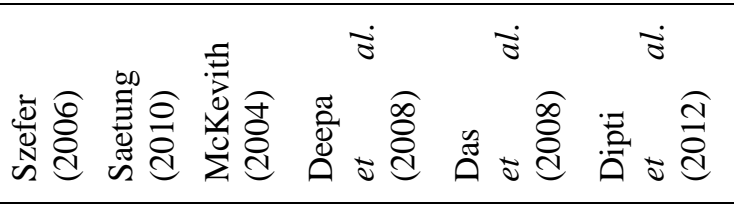


Upadhyay \& Karn: J. Food Sci. Technol. Nepal, Vol. 10 (48-54)

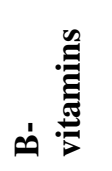

तु

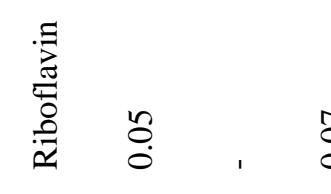

蘩

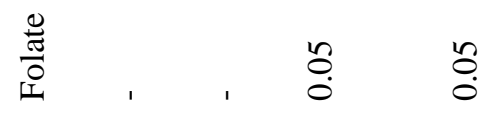

莺

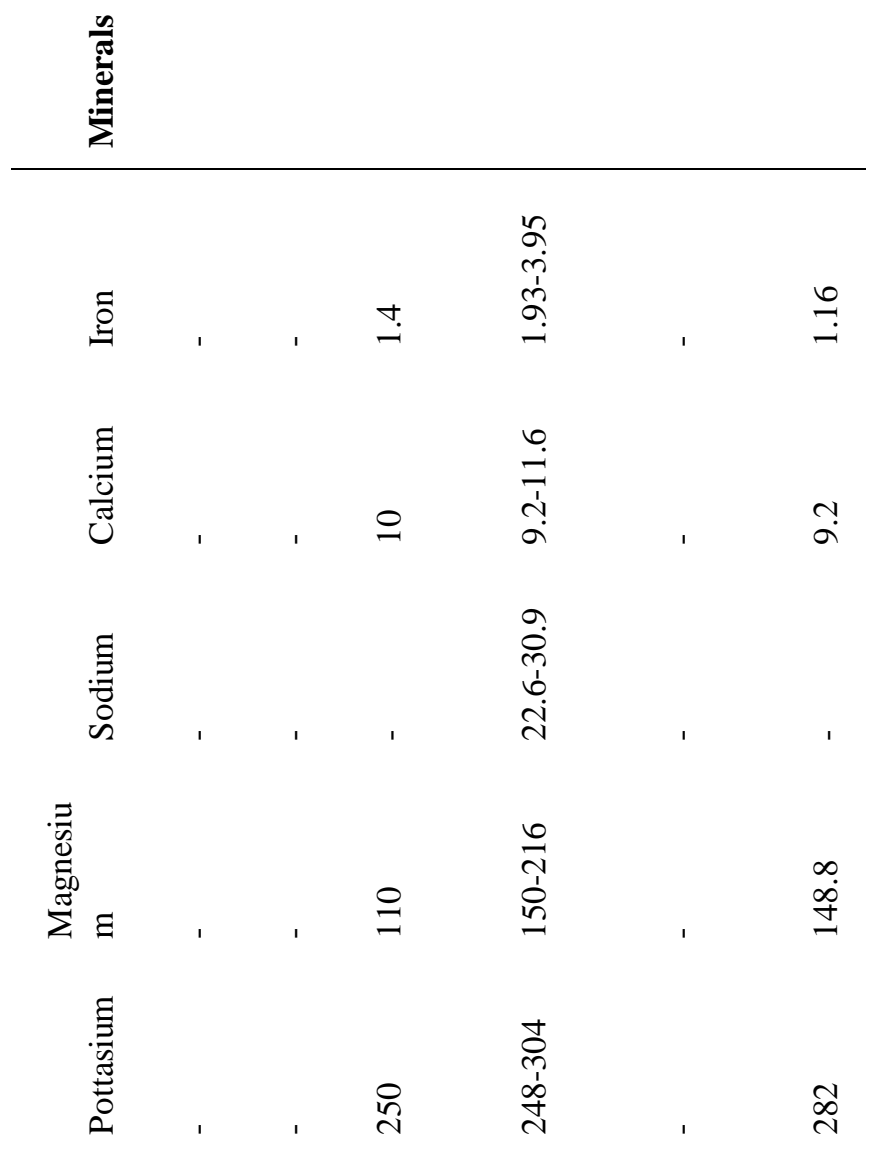

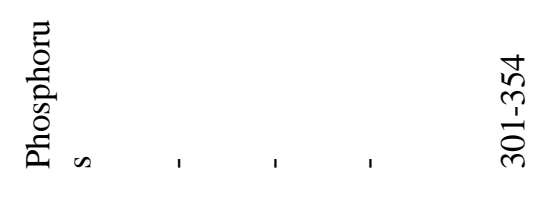

్ำ

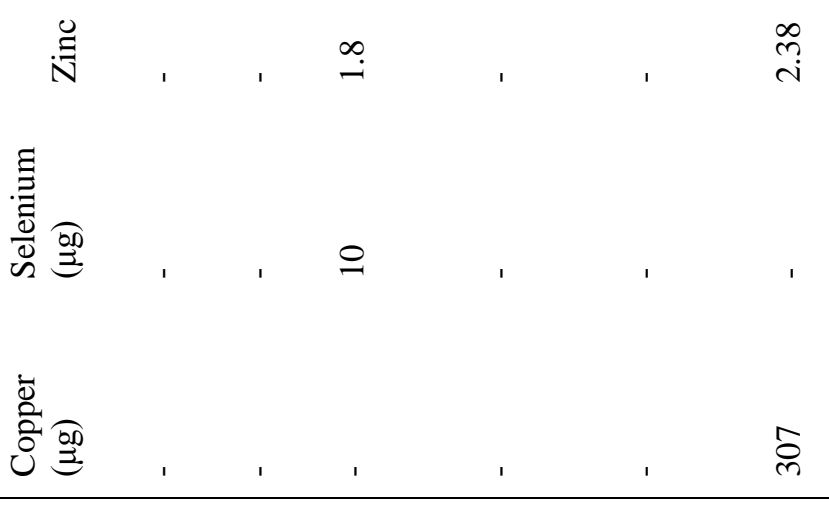

㝏

54 